Tropical Journal of Pharmaceutical Research March 2020; 19 (3): 637-643

ISSN: $1596-5996$ (print); 1596-9827 (electronic)

(C) Pharmacotherapy Group, Faculty of Pharmacy, University of Benin, Benin City, 300001 Nigeria.

\title{
Positive effects of angiotensin-converting enzyme (ACE) inhibitor, captopril, on pentylenetetrazole-induced epileptic seizures in mice
}

\author{
Yasar Tastemur ${ }^{1}$, Erkan Gumus ${ }^{2}$, Merve Ergul ${ }^{3}$, Mustafa Ulu ${ }^{3}$, Recep Akkaya ${ }^{4}$, \\ Aysegul Ozturk ${ }^{5}$, Ahmet Sevki Taskiran ${ }^{5 *}$ \\ ${ }^{1}$ Department of Anatomy, ${ }^{2}$ Departments of Histology and Embryology, Cumhuriyet University School of Medicine, ${ }^{3}$ Department \\ of Pharmacology, Faculty of Pharmacy, Sivas Cumhuriyet University, ${ }^{4}$ Department of Biophysics, ${ }^{5}$ Department of Physiology, \\ Cumhuriyet University School of Medicine, Sivas, Turkey
}

*For correspondence: Email: ahmettaskiran@cumhuriyet.edu.tr; Tel: +90346219 1010; Fax: +90 3462191602

Sent for review: 5 June 2019

Revised accepted: 27 February 2020

\begin{abstract}
Purpose: To evaluate the effects of an angiotensin-converting enzyme (ACE) inhibitor, captopril, on pentylenetetrazole (PTZ)-induced seizures and post-seizure hippocampal injury.

Materials: Thirty-five male Balb-c mice weighing 30 - $33 \mathrm{~g}$ were divided into control, saline PTZ, s(erum physiologic $1 \mathrm{ml} / \mathrm{kg}$ as solvent), positive control (valproic acid $200 \mathrm{mg} / \mathrm{kg}$ ), captopril (25 mg/kg/day for 7 days), and captopril (50 mg/kg/day for 7 days) groups. PTZ (60 mg/kg) was administered thirty minutes after medication administration to induce epileptic seizures. The animals were observed for 30 min to record Racine stages, the time of the first myoclonic jerk (FMJ), and the occurrence of the first generalized tonic-clonic seizure (GTCS). Cornu Ammonis (CA)1, CA2, CA3, and the dentate gyrus (DG) of the hippocampus underwent histopathological examinations. The levels of total oxidant status (TOS), oxidative stress markers (total antioxidant status, TAS), and oxidative stress index (OSI) were measured in the brain tissue.

Results: Compared to PTZ group, $25 \mathrm{mg} / \mathrm{kg}$ captopril decreased seizure scores and delayed FMJ and GTCS $(p<0.05)$. Histopathological assessment demonstrated that both 25 and $50 \mathrm{mg} / \mathrm{kg}$ captopril alleviated neuronal injury in CA1, CA2, CA3, and DG compared to PTZ $(p<0.05)$. Also, TOS and OSI levels in the brain tissue were reduced by both 25 and $50 \mathrm{mg} / \mathrm{kg}$ doses of captopril $(p<0.05)$.

Conclusion: Captopril favorably improves epileptic seizure parameters and acts against post-seizure neuronal injury in the hippocampus. Captopril may be a drug of choice in epileptic individuals with hypertension.
\end{abstract}

Keywords: Captopril, Angiotensin-converting enzyme, Epilepsy, Pentylenetetrazole, Neuronal damage

\begin{abstract}
This is an Open Access article that uses a fund-ing model which does not charge readers or their institutions for access and distributed under the terms of the Creative Commons Attribution License (http://creativecommons.org/licenses/by/4.0) and the Budapest Open Access Initiative (http://www.budapestopenaccessinitiative.org/read), which permit unrestricted use, distribution, and reproduction in any medium, provided the original work is properly credited.

Tropical Journal of Pharmaceutical Research is indexed by Science Citation Index (SciSearch), Scopus, International Pharmaceutical Abstract, Chemical Abstracts, Embase, Index Copernicus, EBSCO, African Index Medicus, JournalSeek, Journal Citation Reports/Science Edition, Directory of Open Access Journals (DOAJ), African Journal Online, Bioline International, Open-J-Gate and Pharmacy Abstracts
\end{abstract}

\section{INTRODUCTION}

Epilepsy is a disorder of the central nervous system and it is characterized by a chronic and progressive nature. In epileptic patients, chronic impairments occur in the nervous system, resulting from episodes of sudden cerebral neuronal discharge. Epilepsy holds the second 
rank among common neurological disorders. The prevalence of epilepsy is estimated to be $2 \%$ and its annual incidence is 50 people/10,0000; contributing to $1 \%$ of the global disease burden. The overall processes in the pathogenesis of epilepsy are complex. It involves an initial silent degeneration, later progressing to neuronal injury and ending in sclerosis. Progressive neuronal sprouting and potential consequent neurogenesis may result in pathological alterations in receptor configuration and channelopathies [1].

Angiotensin-converting enzyme (ACE) is involved in the conversion of circulating angiotensin I to angiotensin II; which is a potent vasoconstrictor and one of the main actors of remodeling processes [2]. ACE inhibitors reduce blood pressure and systemic vascular resistance and improve cardiac functions [3]. Besides the presence of the renin-angiotensin system (RAS) in peripheral tissues, RAS is available in the central nervous system with all of its components including the respective precursors and enzymes [4]. In the central nervous system, angiotensin II acts on angiotensin receptors named AT1 and AT2, playing several roles in the regulation of the cardiovascular system, appetite, stress, memory, and depression [5]. Furthermore, anticonvulsant effects of angiotensin-like peptides have been shown in experimental seizure models when those molecules were applied to brain ventricles directly (i.c.v.), suggesting a potential effect of the RAS system in the control of epileptic seizures [6].

Captopril is one of the most commonly prescribed antihypertensive drugs, selectively and potently inhibiting ACE. It is a prodrug and can pass the blood-brain barrier readily. Systemic administration of captopril is associated with the inhibition of the RAS system in the brain [7]. Compiling evidence in the recent literature demonstrate that reduced central angiotensin II activity caused by ACE inhibitors may be associated with antidepressant and anxiolytic effects [8]. Moreover, it has been suggested that ACE inhibitors, including captopril, enhance learning processes in humans [9].

This study was planned to examine the effects of captopril on PTZ-induced seizures and to prove the neuroprotective effects of captopril on CNS after PTZ administration.

\section{EXPERIMENTAL}

\section{Animals}

Thirty-five male adult BALB-c Albino mice with bodyweights of $30-33 \mathrm{~g}$ were included in the experiment $(n=35)$. The animals included in the experiment were kept at an ambient temperature of $22 \pm 3^{\circ} \mathrm{C}$ and 12 hours of light and 12 hours of dark cycles. Ad libitum access was provided to animals for water and food. It was ensured that animals included in the experiment were acclimatized to laboratory conditions before starting the tests. All experiments were carried out in a blinded setting. The tests were conducted in the hours from 09:00 to 17:00. Each experimental group consisted of 6 animals. The Animal Ethics Committee of Cumhuriyet University approved the study protocol (Approval no:139-65202830-050.04.04-181).

\section{Drug administration}

Pentylenetetrazole (PTZ), captopril, and valproic acid (VPA) (Sigma-Aldrich Co., St Louis, MO, USA) were dissolved in physiological saline. Each drug solution was prepared freshly on the days of the experiments.

\section{Experimental protocols}

The animals were assigned to five experimental groups of 7 randomly. Group 1 was defined as the control group. The mice in group 2 received saline intraperitoneally (i.p.) at a dose of 10 $\mathrm{ml} / \mathrm{kg}$. Group 3 was the positive control group and the mice in this group received a $200 \mathrm{mg} / \mathrm{kg}$ dose of VPA i.p. The mice in group 4 and group 5 received $25 \mathrm{mg} / \mathrm{kg}$ and $50 \mathrm{mg} / \mathrm{kg}$ captopril i.p. for 7 days. Pentylenetetrazole (PTZ) was given to mice to induce epileptic seizures at i.p. doses of $60 \mathrm{mg} / \mathrm{kg}$ after the administration of the last dose of the medicine. The seizure severity was scored based on Racine's Convulsion Scale (RCS). Seizure stages are defined by RCS as follows: $0=$ no convulsion; $1=$ twitching of vibrissae and pinnae; 2 = motor arrest with more pronounced twitching; $3=$ motor arrest with generalized myoclonic jerks; $4=$ tonic-clonic seizure while the animal remained on its feed; 5 $=$ tonic-clonic seizure with loss of the righting reflex; and $6=$ lethal seizure. The mice were observed for 30 minutes after PTZ injection both for behavioral scoring according to RCS and for determining the time of FMJ, which indicated the seizure onset [10]. The animals were sacrificed by decapitation after four hours. The brain tissue obtained from the animals underwent biochemical and histological assessments.

\section{Preparation of brain tissue homogenates}

After mixing the brain tissue samples of the animals with a cold phosphate-buffered saline solution, the tissue samples were homogenized using a mechanical homogenizer (Analytik Jena 
speedmill plus, Jena, Germany). The homogenates were centrifuged at $10000 \times \mathrm{g}$ for $10 \mathrm{~min}$ at a temperature of $4^{\circ} \mathrm{C}$. Then, the supernatants were obtained and stored in ice until biochemical analysis. Beckman Coulter AU680 Chemistry System (Beckman Coulter, Miami, FL, USA) and commercial kits (Rel Assay Diagnostic, Gaziantep, Turkey) were used to measure the levels of TAS and TOS. A Beckman Coulter AU680 Chemistry System (Beckman Coulter, Miami, FL, USA) was used to measure protein concentrations at tissue level based on the principle of the Bradford method [11].

\section{Measurement of total antioxidant status (TAS)}

The TAS concentrations at tissue level were determined with an automated assay method that was previously developed by Erel [12]. The method is based on monitoring the reaction rate of free radicals by measuring the absorbance of colored dianisidyl radicals during free radical reactions starting with the production of hydroxyl radicals in Fenton reaction. Antioxidants in the tissue samples should suppress coloring proportionally to their concentrations [12]. The results were expressed in micromolar Trolox equivalents per milligram tissue protein $(\mu \mathrm{mol}$ Trolox Eq/mg protein).

\section{Measurement of total oxidant status (TOS)}

Tissue TOS concentrations were quantified with the automated assay method of Erel [13]. Because ferrous ion is oxidized to ferric ion when adequate quantities of oxidants are available in the medium, the method allows for quantifying TOS levels by measuring tissue levels of ferric ions with the use of xylenol orange. Hydrogen peroxide was used for the calibration of the assay [13]. The results of the assay were expressed in micromolar hydrogen peroxide equivalents per milligram tissue protein $(\mu \mathrm{mol}$ $\mathrm{H} 2 \mathrm{O} 2 \mathrm{Eq} / \mathrm{mg}$ protein).

\section{Calculation of oxidative stress index (OSI)}

The ratio of TOS to TAS in percentages provided OSI to determine the severity of oxidative stress [13]. OSI was calculated as the ratio of TOS to TAS, expressed as a percentage.

$\mathrm{OSI}=\left[\left(\mathrm{TOS}, \mu \mathrm{mol} \mathrm{H}_{2} \mathrm{O}_{2} \mathrm{Eq} / \mathrm{mg}\right.\right.$ protein $) /$ (TAS, $\mu \mathrm{mol}$ Trolox Eq/mg protein) $\times 100]$.

\section{Histopathologic examination}

After the experiments, a high dose of urethane was administered to the animals. Following this procedure, the mice underwent transcardial perfusion with $100 \mathrm{ml}$ of saline and, then, a 100 $\mathrm{ml}$ fixative solution (formaldehyde $4 \%$ in $0.2 \mathrm{M}$ buffer phosphate at $\mathrm{pH} 1 / 4$ 7.4). After the transcardial perfusion, the mice were decapitated and their brains were collected. Until the time of histological procedures, the collected brains were left in $4 \%$ formalin for at least $72 \mathrm{~h}$. For histopathological examinations, paraffin blocks of tissue samples were prepared. Then, coronal sections of $5 \mathrm{~mm}$ thickness were obtained serially from these paraffin blocks. Ten sections of tissue samples, containing the hippocampus of each mouse were selected by using a systematic randomization method. Then, these tissue samples were mounted on poly-L-lysine coated slides. The tissue samples were stained with Toluidine blue to visualize dark hippocampus neurons. The tissue slides were examined under a light microscope (BX51, Japan) at $\times 40$ magnification (UPlan FI lens, Japan). Digital photographs of the microscopic images of hippocampal CA1, CA2, CA3 regions and the dentate gyrus (DG) were acquired from both hemispheres..A physical dissector method was used to perform a quantitative analysis of the dark neurons.

\section{Statistical analysis}

The data are expressed as mean \pm SEM. A oneway ANOVA followed by Tukey post-hoc test was used to compare the study data. $P<0.05$ indicated statistical significance.

\section{RESULTS}

\section{Epileptic behavior}

The RCS epileptic seizure scores were statistically significantly different between the saline group and the $25 \mathrm{mg} / \mathrm{kg}$ captopril group $(p<0.05)$. However, no statistically significant differences in the RCS scores were found between the saline group and the $50 \mathrm{mg} / \mathrm{kg}$ captopril group $(p>0.05)$ (Table 1$)$. The FMJ time was statistically significantly different between the saline group $(1,24 \pm 0,03 \mathrm{~min})$ and the 25 $\mathrm{mg} / \mathrm{kg}$ captopril group $(p<0.05)$. The difference in FMJ time between the $50 \mathrm{mg} / \mathrm{kg}$ captopril group and the saline group was not statistically significant $(p>0.05)$ (Table 1). The GTCS onset was statistically significantly different between the saline group and the $25 \mathrm{mg} / \mathrm{kg}$ captopril group $(p<0.05)$ but it was not statistically significantly different between the $50 \mathrm{mg} / \mathrm{kg}$ captopril group and the saline group $(p>0.05)$ (Table 1).

\section{Histopathological features}


Dark neurons were identified with the presence of neuronal shrinkage, cytoplasmic eosinophilia,

Table 1: Effect of captopril on the epileptic threshold (latency) in PTZ-treated mice

\begin{tabular}{|c|c|c|c|}
\hline Group & Racine scale & $\begin{array}{l}\text { Latency to the 1st } \\
\text { myoclonic seizure } \\
\text { (min) }\end{array}$ & $\begin{array}{c}\text { Latency to the 1st } \\
\text { generalized tonic-clonic } \\
\text { seizure (min) }\end{array}$ \\
\hline Control & None & None & None \\
\hline $\begin{array}{l}\text { Saline }(1 \mathrm{ml} / \mathrm{kg} \text { serum physiologic, } \\
\text { i.p) + PTZ ( } 60 \mathrm{mg} / \mathrm{kg} \text {, i.p) }\end{array}$ & $5.33 \pm 0.21$ & $1.24 \pm 0.03$ & $1.70 \pm 0.71$ \\
\hline $\begin{array}{l}\text { Positive Control (VPA } 200 \mathrm{mg} / \mathrm{kg} \text {, } \\
\text { i.p.) + PTZ }\end{array}$ & $2.66 \pm 0.21^{*}$ & $2.85 \pm 0.26^{*}$ & None* \\
\hline $\begin{array}{l}\text { Captopril }(25 \mathrm{mg} / \mathrm{kg} / \text { day for } 7 \text { days, } \\
\text { i.p.) + PTZ }\end{array}$ & $4.16 \pm 0.40^{*}$ & $1.89 \pm 0.26^{*}$ & $3.25 \pm 0.29^{*}$ \\
\hline $\begin{array}{l}\text { Captopril ( } 50 \mathrm{mg} / \mathrm{kg} / \mathrm{day} \text { for } 7 \text { days, } \\
\text { i.p.) + PTZ }\end{array}$ & $5.00 \pm 0.25$ & $1.21 \pm 0.08$ & $2.24 \pm 0.34$ \\
\hline
\end{tabular}

Data are presented as mean \pm SEM; ${ }^{*} p<0.05$ in comparison to PTZ group

nuclear pyknosis, and surrounding spongiosis in CA1, CA2, CA3 regions of the hippocampus and DG (Figure 1, Figure 2, Figure 3, and Figure 4). Both the $25 \mathrm{mg} / \mathrm{kg}$ and $50 \mathrm{mg} / \mathrm{kg}$ doses of captopril and VPA significantly prevented dark neuron formation in CA1, CA2, and CA3 regions of the hippocampus and DG after PTZ induced seizures ( $p<0.05$, Figure 5A, 5B, 5C, and 5D).

\section{Biochemical characteristics}

Treating the mice with VPA and $25 \mathrm{mg} / \mathrm{kg}$ and 50 $\mathrm{mg} / \mathrm{kg}$ doses of captopril significantly reduced brain TOS levels compared to the mice in the PTZ group ( $p<0.05)$ (Table 2). Furthermore; VPA and $25 \mathrm{mg} / \mathrm{kg}$ and $50 \mathrm{mg} / \mathrm{kg}$ doses of captopril decreased OSI levels in the brain compared to the PTZ group ( $p<0.05)$ (Table 2). However, neither VPA nor both doses of captopril acted on the brain TAS levels $(p>0.05$, Table 2).

\section{DISCUSSION}

The current study reveals that a potent ACE inhibitor, captopril, had anticonvulsant activity against PTZ-induced seizures; it prevented dark neuron formation in the hippocampus after PTZinduced seizures, and it alleviated oxidative stress after PTZ-induced seizures in brain tissues.

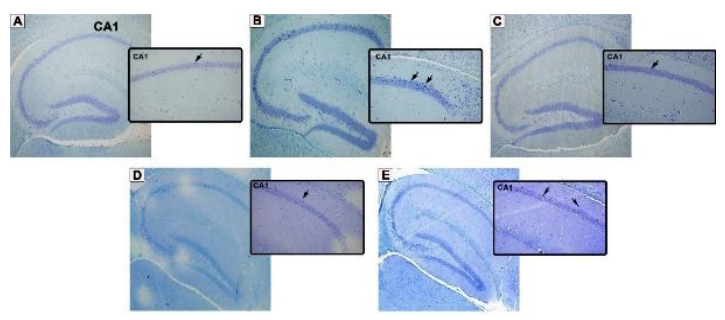

Figure 1: Effect of captopril on neuronal injury following PTZ-induced seizures in mice. Dark neurons are pointed with arrows between the pyramidal cells in the $C A 1$ region.

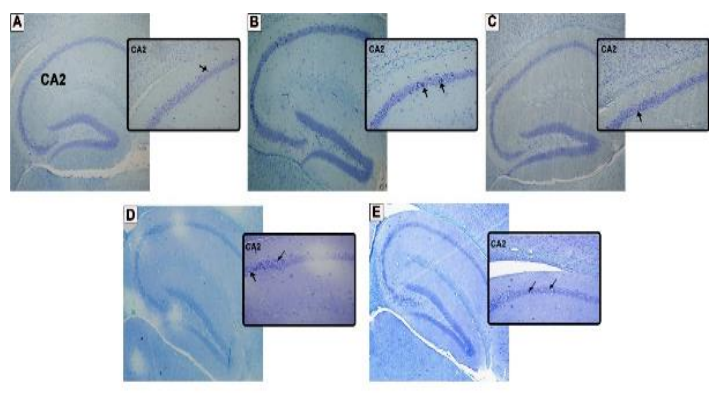

Figure 2: Effect of captopril on neuronal injury following PTZ-induced seizures in mice. Dark neurons are pointed with arrows between the pyramidal cells of the $C A 2$ region

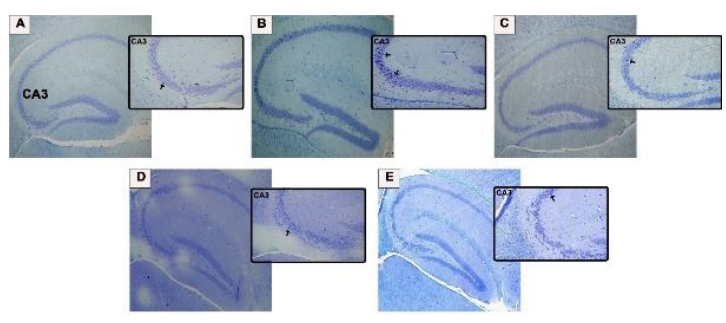

Figure 3: Effect of captopril on neuronal injury following PTZ-induced seizures in mice. Dark neurons are pointed with arrows between the pyramidal cells in the $C A 3$ region.

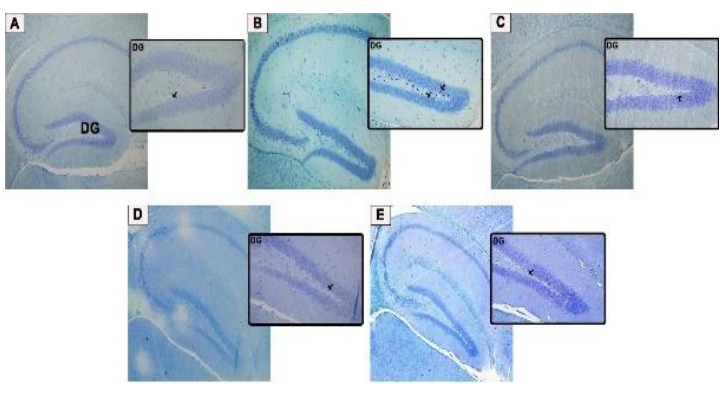


Figure 4: Effect of captopril on neuronal injury following PTZ-induced seizures in mice. Dark neurons are pointed with arrows between the pyramidal cells in $D G$

Table 2: Effects of captopril on the brain TAS, TOS, and OSI levels after PTZ-induced seizures in mice

\begin{tabular}{|c|c|c|c|}
\hline Group & $\begin{array}{c}\text { TAS } \\
\text { ( } \mu \mathrm{mol} / \mathrm{mg} \\
\text { protein) }\end{array}$ & $\begin{array}{c}\text { TOS }(\mu \mathrm{mol} / \mathrm{mg} \\
\text { protein) }\end{array}$ & OSI \\
\hline Control & $0.58 \pm 0.02$ & $1.03 \pm 0.02$ & $190.49 \pm 5.52$ \\
\hline Saline (1 ml/kg serum physiologic) + PTZ (60 mg/kg) & $0.58 \pm 0.00$ & $1.48 \pm 0.03^{a}$ & $280.39 \pm 7.91^{a}$ \\
\hline Positive Control (VPA; 200 mg/kg i.p) + PTZ & $0.58 \pm 0.01$ & $1.11 \pm 0.08^{b}$ & $191.83 \pm 16.79^{b}$ \\
\hline Captopril (25 mg/kg/day for 7days) + PTZ & $0.57 \pm 0.00$ & $1.01 \pm 0.03^{b}$ & $177.48 \pm 5.74^{b}$ \\
\hline Captopril (50 mg/kg/day for 7days) + PTZ & $0.57 \pm 0.00$ & $1.05 \pm 0.02^{b}$ & $186.45 \pm 4.50^{b}$ \\
\hline
\end{tabular}

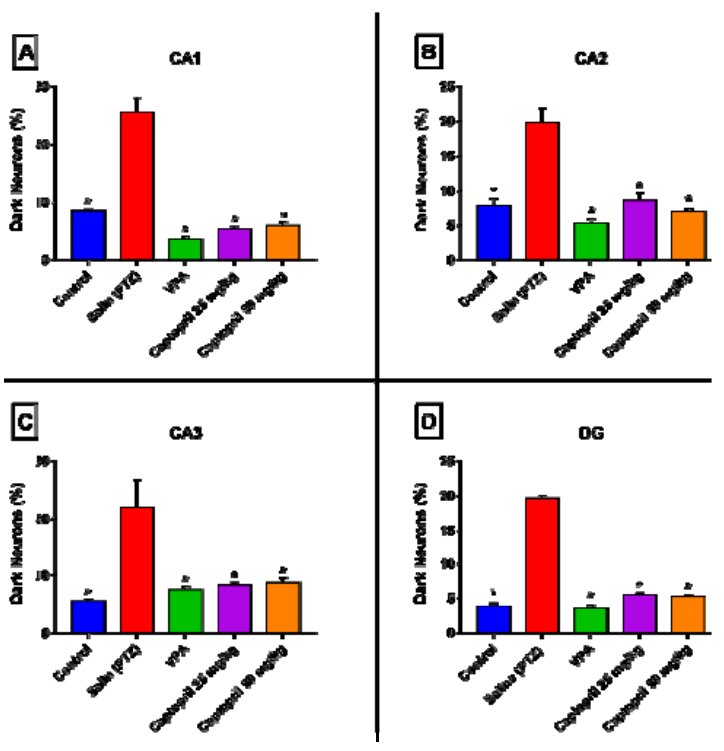

Figure 5: Effects of captopril on neuronal injury after PTZ-induced seizures in mice. The percentages of dark neurons in the $C A 1, C A 2$, and $C A 3$ regions and $D G$ are presented as mean $\pm \mathrm{SEM} ;{ }^{*} p<0.05$ compared to PTZ group

An earlier study has reported that captopril had an anticonvulsant effect against strychnineinduced seizures dose-dependently [14]. Strychnine is a highly selective and potent competitive antagonist of glycine. It shows convulsant activity by acting on strychninesensitive inhibitory glycine receptors in the spinal cord and the brainstem [15]. Therefore, the anticonvulsant effect of captopril can be mediated via the inhibition of spinal postsynaptic glycine [14]. Furthermore, GABAergic inhibitory neurotransmission should be considered to interpret our study results since captopril contains a GABA precursor, proline, in its structure. Moreover, PTZ is a GABAA receptor antagonist [14]. In the central nervous system, GABA acts as the major inhibitory neurotransmitter. Also, it is responsible for seizure control [16]. Interactions between angiotensin II and GABA have been suggested to play a role in seizure susceptibility. Angiotensin II potentiates the inhibition caused by GABAergic agonists. For example, GABA itself and muscimol have been demonstrated to act on the threshold of pentylenetetrazoleinduced seizures. Also, the seizure threshold was increased by the administration of bicuculline, which is a competitive antagonist of $G A B A_{A}$ receptors [6]. Another study showed the allosteric activation of $\mathrm{GABA}_{A}$ receptors after the administration of a combination of captopril and PB [17]. In contrast to these studies, captopril alone showed no effects in maximal electroshock seizure (MES) models but it increased the anticonvulsive effects of CBP and LTG [18]. These different effects have been reported by experimental studies, showing that PTZ acts on the GABA pathways and MES models act on $\mathrm{Na}^{+}$ channels.

In recent years, several studies have shown that oxidative stress and inflammation took a critical part in the pathogenesis of epileptogenesis. It has been reported that these molecules reduce oxidative stress and inflammation levels in tissues and they significantly increased the epileptic threshold [19]. Several experimental studies demonstrate that captopril shows antioxidant and neuroprotective effects under different conditions in the rodent brain. A study reported that captopril improved the memory function by diminishing oxidative stress in the hippocampus [20]. Parallel to the findings of the previous study, a study by Abareshi et al has shown that captopril preserved lipopolysaccharide-induced learning and acted against memory impairments by reducing oxidative stress levels [21]. Captopril has been demonstrated to show positive effects on STZinduced dementia in the rat in association with 
reduced oxidative stress levels [22]. Furthermore, neuroprotective effects of captopril were shown in the dopaminergic neurons of the nigrostriatal system in animal models of Parkinsonism [23]. In the present study, we have demonstrated that captopril reduced oxidative stress parameters similar to the previous studies in the literature as discussed above. This finding can explain the anticonvulsive and neuroprotective effects of captopril on other pathways, excluding its actions on the $G_{B A A}$ receptor.

Dark neurons are basophilic cells that undergo morphological changes in the central nervous system. They might be detected following some pathological conditions; including hypoglycemia, ischemia, and stress in the brain [24]. Epilepsy has also been proposed as a primary reason for dark neuron production [25]. Parallel to the results reported by previous studies in the literature, the present study demonstrated dark neuron formation in the hippocampus after the development of PTZ-induced seizures in mice [26]. Several studies have also confirmed that seizures result in hippocampal injury [27]. These can explain the increased levels of oxidative stress parameters in brain tissue after PTZinduced seizures. These harmful reactive oxygen species can lead to damage in the hippocampus.

\section{CONCLUSION}

The findings of this study indicate that captopril has antiepileptic properties and protects hippocampal neurons after epileptic seizures by reducing oxidative stress levels and increasing GABA flux into neurons. This fact should be taken into consideration in the management of epileptic patients suffering from hypertension. However, further studies are warranted to elucidate the anti-epileptic effects of captopril.

\section{DECLARATIONS}

\section{Conflict of interest}

No conflict of interest is associated with this work.

\section{Contribution of authors}

We declare that the authors named in this article conducted this study. The authors will carry all liabilities concerning rights relating to the content of this study. The paper was read thoroughly and confirmed by all authors.

\section{Open Access}

This is an Open Access article that uses a funding model which does not charge readers or their institutions for access and distributed under the terms of the Creative Commons Attribution License (http://creativecommons.org/licenses/by/ 4.0) and the Budapest Open Access Initiative (http://www.budapestopenaccessinitiative.org/rea d), which permit unrestricted use, distribution, and reproduction in any medium, provided the original work is properly credited.

\section{REFERENCES}

1. Curia G, Lucchi C, Vinet J, Gualtieri F, Marinelli C, Torsello A, Costantino L, Biagini G. Pathophysiogenesis of Mesial Temporal Lobe Epilepsy: Is Prevention of Damage Antiepileptogenic? Curr Med Chem 2014; 21(6): 663-688.

2. Johnston C. Biochemistry and Pharmacology of the Renin-Angiotensin System. Drugs 1990;(39):21-31.

3. Thind GS. Angiotensin converting enzyme inhibitors: Comparative structure, pharmacokinetics, and pharmacodynamics. Cardiovasc Drugs Ther 1990;4(1):199-206.

4. Wright JW, Harding JW. Important roles for angiotensin III and IV in the brain renin- angiotensin system. Brain Res Rev 1997; 25(1): 96-124.

5. Wright JW, Yamamoto BJ, Harding JW. Angiotensin receptor subtype mediated physiologies and behaviors: New discoveries and clinical targets. Prog Neurobiol2008;84(2):157-81.

6. Tchekalarova J, Georgiev V. Angiotensin peptides modulatory system: How is it implicated in the control of seizure susceptibility? Life Sci 2005;76(9):955-70.

7. Evered MD, Robinson MM, Richardson MA. Captopril given intracerebroventricularly, subcutaneously or by gavage inhibits angiotensin-converting enzyme activity in the rat brain. Eur J Pharmacol 1980;68(4):443-9.

8. Gard PR. The role of angiotensin II in cognition and behaviour. Eur J Pharmacol 2002;438(1-2):1-14.

9. Braszko JJ, Karwowska-Polecka W, Halicka D, Gard PR. Captopril And Enalapril Improve Cognition And Depressed Mood In Hypertensive Patients. J Basic Clin Physiol Pharmacol 2003;14(4):323-43.

10. Racine RJ. Modification of seizure activity by electrical stimulation: I. after-discharge threshold. Electroencephalogr Clin Neurophysiol 1972;32(3):26979.

11. Bradford MM. A rapid and sensitive method for the quantitation of microgram quantities of protein utilizing the principle of protein-dye binding. Anal Biochem 1976;(72):248-54.

12. Erel O. A novel automated method to measure total antioxidant response against potent free radical reactions. Clin Biochem 2004; 37(2): 112-119. 
13. Erel O. A new automated colorimetric method for measuring total oxidant status. Clin Biochem 2005; 37(2): 112-119.

14. Mıñano FJ, Serrano JS, Sancıbrıán M, Serrano MI. Effect of peptıdyl-dipeptıdase inhibitors in experimental convulsions in mice. Fundam Clin Pharmacol 1987;1(2):77-83.

15. Rajendra S, Lynch JW, Schofield PR. The glycine receptor. Pharmacol Ther 1997.73(2):121-46.

16. Czuczwar SJ, Patsalos PN. The new generation of GABA enhancers: Potential in the treatment of epilepsy. CNS Drugs 2001;15(5):339-50.

17. Kwan P, Sills GJ, Brodie MJ. The mechanisms of action of commonly used antiepileptic drugs. Pharmacol Ther 2001;90(1):21-34.

18. Hamada NM, Ashour RH, Shalaby AA, El-Beltagi HM. Calcitonin potentiates the anticonvulsant and antinociceptive effects of valproic acid and pregabalin in pentylenetetrazole-kindled mice. Eur J Pharmacol 2018;(818):351-355.

19. Abraham J, Fox PD, Condello C, Bartolini A, Koh S. Minocycline attenuates microglia activation and blocks the long-term epileptogenic effects of early-life seizures. Neurobiol Dis 2012;46(2):425-30.

20. Bild W, Hritcu L, Stefanescu C, Ciobica A. Inhibition of central angiotensin II enhances memory function and reduces oxidative stress status in rat hippocampus. Prog Neuro-Psychopharmacology Biol Psychiatry 2013;(43):79-88.

21. Abareshi A, Hosseini M, Beheshti F, Norouzi F, Khazaei M, Sadeghnia HR, Boskabady MH, Shafei MN,
Anaeigoudari A. The effects of captopril on lipopolysaccharide induced learning and memory impairments and the brain cytokine levels and oxidative damage in rats. Life Sci 2016;(167):46-56.

22. Abbassi YA, Mohammadi MT, Foroshani MS, Sarshoori JR. Captopril and valsartan may improve cognitive function through potentiation of the brain antioxidant defense system and attenuation of oxidative/nitrosative damage in STZ-induced dementia in rat. Adv Pharm Bull 2016;6(4):531-539.

23. Sonsalla $P K$, Coleman C, Wong LY, Harris $S L$, Richardson JR, Gadad BS, Li W, German DC. The angiotensin converting enzyme inhibitor captopril protects nigrostriatal dopamine neurons in animal models of parkinsonism. Exp Neurol 2013;(250):376383.

24. Kherani ZS, Auer RN. Pharmacologic analysis of the mechanism of dark neuron production in cerebral cortex. Acta Neuropathol 2008;116(4):447-52.

25. Söderfeldt B, Kalimo H, Olsson $Y$, Siesjö BK. Bicucullineinduced epileptic brain injury - Transient and persistent cell changes in rat cerebral cortex in the early recovery period. Acta Neuropathol 1983;62(1-2):87-95.

26. Taskıran AS, Gumus E, Gunes H, Cetindag A, Ozdemir E. The Protective Effects of Vitamin $B 12$ on Pentylenetetrazole-Induced Seizures in Rats. Anat Physiol Biochem Int J 2018;4(1):1-5.

27. Pitkänen A, Tuunanen J, Kälviäinen $R$, Partanen $K$, Salmenperä T. Amygdala damage in experimental and human temporal lobe epilepsy. Epilepsy Res 1998;32(12):233-53. 